\title{
Application of whey protein isolate in bone regeneration: Effects on growth and osteogenic differentiation of bone-forming cells
}

\author{
Timothy E. L. Douglas, ${ }^{*} †$ Marta Vandrovcová, $\ddagger^{1}$ Nikola Kročilová,ł Julia K. Keppler,§ Jana Zárubová,ł \\ Andre G. Skirtach, ${ }^{*}$ and Lucie Bačákováł \\ *Department of Molecular Biotechnology, Faculty of Bioscience Engineering, Ghent University, Coupure Links 653,9000 Gent, Belgium \\ †Engineering Department, Gillow Avenue, Lancaster University, Lancaster LA1 4YW, United Kingdom \\ †Department of Biomaterials and Tissue Engineering, Institute of Physiology of the Czech Academy of Sciences, Videnska 1083, 14220 Prague, \\ the Czech Republic \\ §Department of Food Technology, Institute of Human Nutrition and Food Science, Christian-Albrechts-Universität zu Kiel, Heinrich-Hecht Platz 10, \\ 24118 Kiel, Germany \\ \#Centre for Nano- and Biophotonics, Ghent University, 9000 Ghent, Belgium
}

\section{ABSTRACT}

Recently, milk-derived proteins have attracted attention for applications in the biomedical field such as tissue regeneration. Whey protein isolate (WPI), especially its main component $\beta$-lactoglobulin, can modulate immunity and acts as an antioxidant, antitumor, antiviral, and antibacterial agent. There are very few reports of the application of WPI in tissue engineering, especially in bone tissue engineering. In this study, we tested the influence of different concentrations of WPI on behavior of human osteoblast-like Saos-2 cells, human adipose tissue-derived stem cells (ASC), and human neonatal dermal fibroblasts (FIB). The positive effect on growth was apparent for Saos-2 cells and FIB but not for ASC. However, the expression of markers characteristic for early osteogenic cell differentiation [type-I collagen $(C O L 1)$ and alkaline phosphatase $(A L P)]$ as well as ALP activity, increased dose-dependently in ASC. Importantly, Saos- 2 cells were able to deposit calcium in the presence of WPI, even in a proliferation medium without other supplements that support osteogenic cell differentiation. The results indicate that, depending on the cell type, WPI can act as an enhancer of cell proliferation and osteogenic differentiation. Therefore, enrichment of biomaterials for bone regeneration with WPI seems a promising approach, especially due to the low cost of WPI.

Key words: whey protein isolate, cell proliferation, osteogenic differentiation, adipose-derived stem cell

Received May 5, 2017.

Accepted September 14, 2017.

${ }^{1}$ Corresponding author: Marta.Vandrovcova@fgu.cas.cz

\section{INTRODUCTION}

The human population, especially in developed countries, is aging, which makes age-related health issues more important. Diseases of the locomotive system, such as fractures, osteoporosis, rheumatoid arthritis, and others, are the second most frequent diseases after the cardiovascular diseases (Schliemann et al., 2015). Many growth factors and hormones are known for their supportive effect on bone growth (e.g., bone morphogenetic protein 2, BMP-2); nevertheless, their isolation and production can be complicated and expensive (Bhattacharya et al., 2016). Moreover, there are indications that the application of BMP-2 may lead to negative side effects (Shields et al., 2006). Hence, the need exists for effective and inexpensive alternatives.

Despite the controversy of milk consumption in adulthood (Pereira, 2014), milk is a cheap source of compounds needed for bone development and regeneration. Milk contains 2 main groups of proteins: caseins ( $80 \%$ of all proteins in ruminant milk), consisting of 4 major proteins, and whey protein $(20 \%$ of all proteins in ruminant milk), consisting of 2 main components, $\beta$-LG and $\alpha-\mathrm{LA}$, and smaller amounts of serum albumin, lactoferrin, and other proteins (Do et al., 2016). Whey protein was considered a waste product in the dairy industry. It contains the aforementioned compounds in different ratios depending on the method of cheese manufacture. Various types of whey protein exist, such as reduced-lactose whey, demineralized whey, whey protein concentrates, and whey protein isolates (WPI; Walzem et al., 2002). Whey proteins contain a higher amount of AA rich in sulfur compared with caseins. It is believed that proteins rich in sulfur provide a higher protein efficiency ratio (i.e., weight gain to intake of protein during the tested period). Moreover, these types of proteins are important in immune modulation (Bounous and Gold, 1991). Whey proteins also consist 
of branched-chain AA, which promote protein synthesis in muscle cells (Walzem et al., 2002). As mentioned above, the major component of WPI is $\beta$-LG. It is an interesting protein from a biological point of view. It is a major whey protein of ruminants and belongs to the lipocalin protein family, which is responsible for a wide variety of functions, especially ligand-binding functions (Flower et al., 2000). The $\beta$-barrel (calyx) within the $\beta$-LG molecule exhibits ligand-binding properties and it can accommodate hydrophobic molecules, such as vitamins $\mathrm{A}$ and $\mathrm{D}$ and cholesterol (Kontopidis et al., 2004). Because of this affinity of $\beta$-LG for hydrophobic molecules, it is used as a carrier protein to improve their uptake and solubility (Ha et al., 2013; Lee et al., 2013; Diarrassouba et al., 2015).

Many studies have focused on the effect of consumption of milk or its derivatives in vivo (Parodi, 2007; Yamaguchi et al., 2014); however, a relatively small number of studies have focused on the performance of specific compounds in vitro (Gillespie et al., 2015; Pyo et al., 2016). In particular, $\beta$-LG has been used to influence intestinal and cancer cells. However, applications outside the digestive system have not been studied. For example, the effect of WPI on bone-forming cells remains unexplored.

In this study, we tested the influence of different concentrations of WPI rich in $\beta$-LG (80\% wt) on cell growth and differentiation. Three cell types were studied: human osteoblast-like Saos-2 cells, human adiposederived stem cells (ASC), and human neonatal dermal fibroblasts (FIB). Saos-2 cells, a cell line of relatively mature cells with standardized behavior, were chosen as being representative of bone cells (Czekanska et al., 2012). The human ASC were chosen as being representative of mesenchymal stem cells. Recently, it was proven that ASC have comparable morphology, phenotype, and potential differentiation ability to bone marrow mesenchymal stem cells (Levi and Longaker, 2011; Bhattacharya et al., 2016). Additionally, due to their subcutaneous localization, these cells are easily accessible by liposuction in relatively high amounts. The yield of ASC in the stromal vascular fraction of a lipoaspirate can reach 1 to $5 \%$; this percentage differs depending on the harvesting site (Jurgens et al., 2008; Kolaparthy et al., 2015). For comparison, the isolation of bone marrow mesenchymal stem cells requires a painful procedure, and a relatively small percentage of stem cells is present in the bone marrow aspirate (500 times less than ASC; Mizuno, 2009). Fibroblasts represent a primoculture of cells, which are considered an excellent cell model to study many aspects of cell physiology (Tschumperlin, 2013).

In this study, the effect of WPI on Saos-2 cells, ASC, and FIB were compared using following evaluations:
(1) cell proliferation by a real-time detecting system, (2) expression of cell differentiation markers by realtime quantitative (q)PCR, (3) activity of alkaline phosphatase (ALP), and (4) deposition of calcium.

\section{MATERIALS AND METHODS}

\section{Preparation, Composition, and Sterilization of WPI}

Whey protein isolate (BiPRO, Davisco Foods International Inc., Eden Prairie, MN) with $97.7 \%$ protein and $75 \% \beta$-LG in DM (according to the manufacturer's specification) was used. Our HPLC analysis according to Keppler et al. (2014; see Supplemental Figure S1; https://doi.org/10.3168/jds.2017-13119) confirmed that the WPI dissolved in cell culture medium comprised approximately $80 \% \quad \beta$-LG genetic variants b and a (elution time 19.2 and $20.1 \mathrm{~min}$, respectively) and some $\alpha$-LA (elution time $10.7 \mathrm{~min}$ ). This is in accordance with previous analyses of the same WPI dissolved in water (Keppler et al., 2017; Keppler and Schwarz, 2017). As expected, there was no protein loss due to filtration.

\section{Isolation and Characterization of ASC}

The ASC were obtained in compliance with the tenets of the Declaration of Helsinki for experiments with human tissues and under an ethical approval issued by the Ethical Committee in the Bulovka Hospital in Prague, Czech Republic (August 21, 2014) and by the Institute of Physiology CAS in Prague, Czech Republic (August $18,2014)$. Informed consent was obtained from the patient before the liposuction procedure. Lipoaspirate $(50 \mathrm{~mL})$ was collected from the belly area of a 40-yrold female patient. Liposuction was performed under negative pressure $(-700 \mathrm{mmHg})$, and the ASC were isolated by a procedure described previously (Estes et al., 2010). The fat was washed several times with PBS (Sigma-Aldrich, St. Louis, MO) to remove remaining blood, and then digested with $0.1 \%$ collagenase typeI (Worthington, Lakewood, NJ) for $1 \mathrm{~h}$ at $37^{\circ} \mathrm{C}$. The sample was then centrifuged $(300 \times g)$ for $5 \mathrm{~min}$ at $21^{\circ} \mathrm{C}$. The tube was shaken vigorously for $10 \mathrm{~s}$ and centrifuged under the same conditions one more time. The pellet of stromal vascular fraction was obtained and remaining supernatant (fat) removed. Then, Dulbecco's modified Eagle's medium (DMEM; Gibco/Thermo Fisher Scientific, Waltham, MA) supplemented with $10 \%$ fetal bovine serum (Gibco), $10 \mathrm{ng} / \mathrm{mL}$ human fibroblast growth factor-2 (FGF-2, Cat. No. Z03116-1, GenScript, Piscataway, NJ), and gentamicin (40 $\mu \mathrm{g}$ / $\mathrm{mL}$, LEK, Ljubljana, Slovenia) was added, and the pellet was filtered through a cell filter with $100-\mu \mathrm{m}$ 
pores (Millex syringe-driven filter unit, Merck, Darmstadt, Germany; Estes et al., 2010). Finally, the cells were seeded at an density equivalent to $0.16 \mathrm{~mL}$ of the original liposuction aspirate per $\mathrm{cm}^{2}$. The successful isolation of ASC was confirmed by flow cytometry. The population of ASC was positive for CD73 (ecto-5'nucleotidase), CD90 (immunoglobulin Thy-1), CD105 (endoglin), CD29 (fibronectin receptor), and CD146 (receptor for laminin) and negative for CD31 (platelet endothelial cell adhesion molecule), CD34 (hematopoietic progenitor cell antigen), and CD45 (leucocytes) surface markers (Supplemental Figure S2; https://doi .org/10.3168/jds.2017-13119).

\section{Real-Time Monitoring of Cell Adhesion and Proliferation}

The cellular response of osteoblast-like Saos-2 cells (purchased from European Collection of Cell Cultures, Salisbury, UK), ASC (in passage 2), and FIB (in passage 2; purchased from Lonza, Basel, Switzerland) to different WPI concentrations was studied at $37^{\circ} \mathrm{C}$ in a humidified air atmosphere containing $5 \% \mathrm{CO}_{2}$ for 117 h. The Saos-2 cells, FIB, and ASC were cultured in McCoy's 5A medium, DMEM, and DMEM supplemented with FGF-2, respectively. All of the media contained fetal bovine serum ( $15 \%$ for Saos- 2 cells, $10 \%$ for FIB and ACS) and gentamicin $(40 \mu \mathrm{g} / \mathrm{mL})$. A real-time cell analyzer (xCelligence, Roche Applied Science, Mannheim, Germany) was used to evaluate the growth of cells in the prepared solutions continuously over a 5-d time span. The cells were seeded into 96-well sensory E plates (E-Plate 96, Cat. No. 05232368001; BioTech a.s., Prague, Czech Republic), and background impedance was measured in each well. The cell densities were 3,500 cells/well $\left(\sim 10,300\right.$ cells $\left./ \mathrm{cm}^{2}\right)$ for Saos- 2 and FIB, and 7,000 cells/well $\left(\sim 20,600\right.$ cells $\left./ \mathrm{cm}^{2}\right)$ for ASC. The final volume was $200 \mu \mathrm{L}$. After $24 \mathrm{~h}$, cultivation medium was exchanged for appropriate media containing specific concentrations of WPI $(0,50,300$, or $800 \mu \mathrm{g} / \mathrm{mL})$. Each concentration was added to the wells in heptaplicates. Cell index values (reflecting cell attachment, spreading, and proliferation) were calculated automatically by the instrument according to the formula

Cell index $=($ impedance at individual time interval - background impedance) $/ 15 \Omega$.

\section{Real-Time Quantitative PCR of Markers of Osteogenic Cell Differentiation}

Real-time quantitative PCR was used to determine the effect of WPI content on the level of expression of the genes COL1 (Saos-2, ASC, FIB), ALP (Saos-2, ASC), and $O C$ (Saos-2, ASC). The expression of transcription factor $R U N X 2$, also involved in osteogenic cell differentiation, was evaluated in Saos-2 and ASC. Cells were grown in the tested solutions for $7 \mathrm{~d}$. Total RNA was extracted from Saos-2, ASC, and FIB using Total RNA purification Micro Kit (Cat. No. 35300; Norgene Biotek Corp., Thorold, ON, Canada) according to the manufacturer's instructions. The mRNA concentration was measured using NanoPhotometer S/N (Implen GmbH, Munich, Germany), and cDNA was synthesized with the ProtoScript M-MuLV First Strand cDNA Synthesis kit (Cat. No. E6300S; New England BioLabs, Ipswich, MA) using $250 \mathrm{ng}$ of total RNA and oligo$\mathrm{dT}$ primers. The reaction was performed in T-Personal Thermocycler (Biometra GmbH, Göttingen, Germany). The qPCR primers were purchased from Generi Biotech Ltd. (Hradec Králové, Czech Republic) and are listed in Table 1. The primers were designed according to the literature (Frank et al., 2002; Reseland et al., 2006; Franke et al., 2007; Zhang et al., 2010). The qPCR was performed using SYBR Green (Roche, Mannheim, Germany) in a total reaction volume of $20 \mu \mathrm{L}$ and $\mathrm{iCy}-$ cler detection system (iQ 5 Multicolor Real-Time PCR Detection System, Bio-Rad Laboratories, Hercules, CA) with cycling parameters of $10 \mathrm{~min}$ at $95^{\circ} \mathrm{C}, 40$ cycles of $15 \mathrm{~s}$ at $95^{\circ} \mathrm{C}$ and $1 \mathrm{~min}$ at $60^{\circ} \mathrm{C}$, followed by a melt curve. Assays were conducted in quadruplicates. Data were analyzed by the $2^{-\Delta \Delta \mathrm{Cq}}$ method. The point at which the PCR product was first detected above a fixed threshold (termed cycle threshold, $\mathbf{C}_{\mathbf{q}}$ ) was determined for each sample. Changes in the expression of target genes were calculated using the equation:

$$
\begin{gathered}
\Delta \Delta \mathrm{C}_{\mathrm{q}}=\left(\mathrm{C}_{\mathrm{q}}^{\text {target }}-\mathrm{C}_{\mathrm{q}}^{\mathrm{GAPDH}}\right)_{\text {sample }} \\
-\left(\mathrm{C}_{\mathrm{q}}^{\text {target }}-\mathrm{C}_{\mathrm{q}}^{\mathrm{GAPDH}}\right)_{\text {calibrator }} .
\end{gathered}
$$

Glyceraldehyde 3-phosphate dehydrogenase (GAP$D H$ ) was used as a housekeeping gene, and data were normalized to the expression levels of cells grown in medium without WPI (0, calibrator).

\section{Alkaline Phosphatase Activity}

We studied the influence of different concentrations of WPI on activity of ALP in Saos-2 cells, FIB, and ASC. Cells were cultured in McCoy's 5A medium, DMEM, and DMEM supplemented with FGF-2, respectively. All of the media contained fetal bovine serum ( $15 \%$ for Saos- 2 cells, $10 \%$ for ACS and FIB) and gentamicin (40 $\mu \mathrm{g} / \mathrm{mL}$ ). The cells were seeded into 24-well cell culture plates (TPP, Trasadingen, Switzerland). The cell densities were 28,000 cells/well $\left(\sim 15,000\right.$ cells $\left./ \mathrm{cm}^{2}\right)$ for Saos- 
2 cells and FIB, and 10,000 cells/well ( $\sim 5,400$ cells/ $\mathrm{cm}^{2}$ ) for ASC. The final volume was $1 \mathrm{~mL}$. After $24 \mathrm{~h}$, the cultivation medium was exchanged for appropriate media containing specific concentrations of WPI $(0,50$, 300 , or $800 \mu \mathrm{g} / \mathrm{mL}$ ). After $7 \mathrm{~d}$ of cultivation, the cell layers were washed twice with PBS; then, $1 \mathrm{~mL}$ of the substrate solution $[1 \mathrm{mg} / \mathrm{mL} p$-nitrophenyl phosphate in substrate buffer ( $50 \mathrm{~m} M$ glycine, $1 \mathrm{mM} \mathrm{MgCl}, \mathrm{pH}$ 10.5; Sigma-Aldrich)] was added directly to the cells. The reaction was performed for 5 min (Saos-2 cells), 15 min (ASC), or $21 \mathrm{~min}$ (FIB) at room temperature; the substrate solution was then removed and mixed with the same volume of $1 M \mathrm{NaOH}$ solution. The absorbance $(405 \mathrm{~nm})$ of the samples was measured together with the absorbance of the known concentrations of $p$ nitrophenol diluted in 0.02 $M \mathrm{NaOH}(9-90 \mu M$; SigmaAldrich). The results were normalized by the cell index. The experiments were performed in quadruplicate and repeated 3 times.

\section{Calcium Deposition}

The influence of different concentrations of WPI on calcium deposition of Saos-2 cells was studied. Cells were cultured in McCoy's 5A supplemented with $15 \%$ fetal bovine serum and $40 \mu \mathrm{g} / \mathrm{mL}$ gentamicin. The cells were seeded into 24 -well cell culture plates (TPP). The cell density was 28,000 cells/well $\left(\sim 15,000\right.$ cells $\left./ \mathrm{cm}^{2}\right)$. The final volume was $1 \mathrm{~mL}$. After $24 \mathrm{~h}$, cultivation medium was exchanged for appropriate medium containing specific concentrations of WPI $(0,50,300$, or $800 \mu \mathrm{g} / \mathrm{mL}$ ). After 7, 14, and $21 \mathrm{~d}$ of cultivation, the cell layers were rinsed with PBS, dried, and lysed in 0.5 $M \mathrm{HCl}$ for $24 \mathrm{~h}$ at $4^{\circ} \mathrm{C}$. The calcium in the cell lysates and standards was directly determined using the Calcium Colorimetric Assay Kit (Biovision Inc., Milpitas, $\mathrm{CA}$ ) according to the manufacturer's protocol. The experiments were performed in quadruplicate and were repeated 3 times. The results were normalized to the cell index.

\section{Statistical Evaluation}

The quantitative data of cell proliferation were presented as mean \pm standard deviation from 7 measurements. The PCR, ALP activity, and Ca deposition data were presented as mean \pm standard deviation of 4 measurements. The statistical analyses were performed using SigmaStat (Jandel Corp./Systat Software Inc., San Jose, CA) by one-way ANOVA and the StudentNewman-Keuls method. The value $P \leq 0.05$ was considered significant $(P \leq 0.01$ for PCR data).

\section{RESULTS AND DISCUSSION}

This study established a positive effect of WPI on the proliferation of Saos-2 cells and FIB (Figure 1); the growth of ASC was less sensitive. In these cells, a slightly positive influence of WPI was demonstrated only at the highest concentration $(800 \mu \mathrm{g} / \mathrm{mL})$. Nevertheless, the values at $800 \mu \mathrm{g} / \mathrm{mL}$ WPI were not significantly different from those at lower WPI concentrations. An earlier study $(\mathrm{Xu}, 2009)$ investigated the proliferative effect of 2 concentrations of whey protein (0.02 and $0.1 \mathrm{mg} / \mathrm{mL}$ ) on rat osteoblasts. That author found a positive effect of whey protein on the cell proliferation, which was dose-dependent, similar to our results. In another study, it was reported that $\beta$-LG (a major part of WPI) improved the proliferation of enteroendocrine cells (Gillespie et al., 2015). Those authors reported proliferation-stimulating effects of $\beta$-LG only within a concentration window of 312.5 to $2,500 \mu \mathrm{g} / \mathrm{mL}$. In another study on mouse spleen resting cells, $\beta-L G$ stimulated proliferation in a concentration range of 50 to $500 \mu \mathrm{g} / \mathrm{mL}$ in the time range 12 to $96 \mathrm{~h}$ (Mahmud et al., 2004). These $\beta$-LG concentration ranges are similar to those investigated in the present study, where 50 to $800 \mu \mathrm{g} / \mathrm{mL}$ WPI represented 40 to $640 \mu \mathrm{g} / \mathrm{mL} \beta$-LG; within this range, the proliferation of Saos-2 cell and fibroblasts was promoted. In another study using hybridomas, $\beta$-LG concentrations between 750 and 3,000

Table 1. Oligonucleotide primers for real-time quantitative PCR amplifications

\begin{tabular}{|c|c|c|}
\hline Gene & Primer sequence & $\begin{array}{l}\text { Product } \\
\text { size (bp) }\end{array}$ \\
\hline$R U N X 2$ & $\begin{array}{l}\text { Forward: 5'-GCCTTCAAGGTGGTAGCCC-3' } \\
\text { Reverse: 5'-CGTTACCCGCCATGACAGTA-3' }\end{array}$ & 100 \\
\hline COL1 & $\begin{array}{l}\text { Forward: 5'-CAGCCGCTTCACCTACAGC-3' } \\
\text { Reverse: } 5^{\prime} \text {-TTTTGTATTCAATCACTGTCTTGCC-3' }\end{array}$ & 83 \\
\hline$A L P$ & $\begin{array}{l}\text { Forward: 5'-GACCCTTGACCCCCACAAT-3' } \\
\text { Reverse: 5'-GCTCGTACTGCATGTCCCCT-3' }\end{array}$ & 68 \\
\hline$O C$ & $\begin{array}{l}\text { Forward: 5'-GAAGCCCAGCGGTGCA-3' } \\
\text { Reverse: 5'-CACTACCTCGCTGCCCTCC-3' }\end{array}$ & 70 \\
\hline$G A P D H$ & $\begin{array}{l}\text { Forward: 5'-TGCACCACCAACTGCTTAGC-3' } \\
\text { Reverse: 5'-GGCATGGACTGTGGTCATGAG-3' }\end{array}$ & 87 \\
\hline
\end{tabular}


$\mu \mathrm{g} / \mathrm{mL}$ stimulated proliferation after $48 \mathrm{~h}$ (Moulti-Mati et al., 1991). The positive effect of $\beta$-LG on osteogenic differentiation needs to be elucidated in further studies. Finally, lactoferrin, another milk-derived protein, stimulated the adhesion, growth, and osteogenic differentiation of Saos-2 cells in our earlier study (Vandrovcova at al., 2015).

Quantitative PCR was performed on d 7 (Figure 2). Markers of osteogenic differentiation were measured in
Saos-2 cells and ASC. The transcription factor RUNX2, an early marker of osteogenic differentiation, was evaluated in Saos-2 cells and ASC. Despite the apparent tendency in ASC, only the highest concentration of WPI significantly promoted expression of RUNX2 in Saos-2 cells. The RUNX2 protein is a potent osteoblast transcription factor, which promotes expression of type-I collagen in the early differentiation stage (Fakhry et al., 2013). However, overexpression of RUNX2 leads to
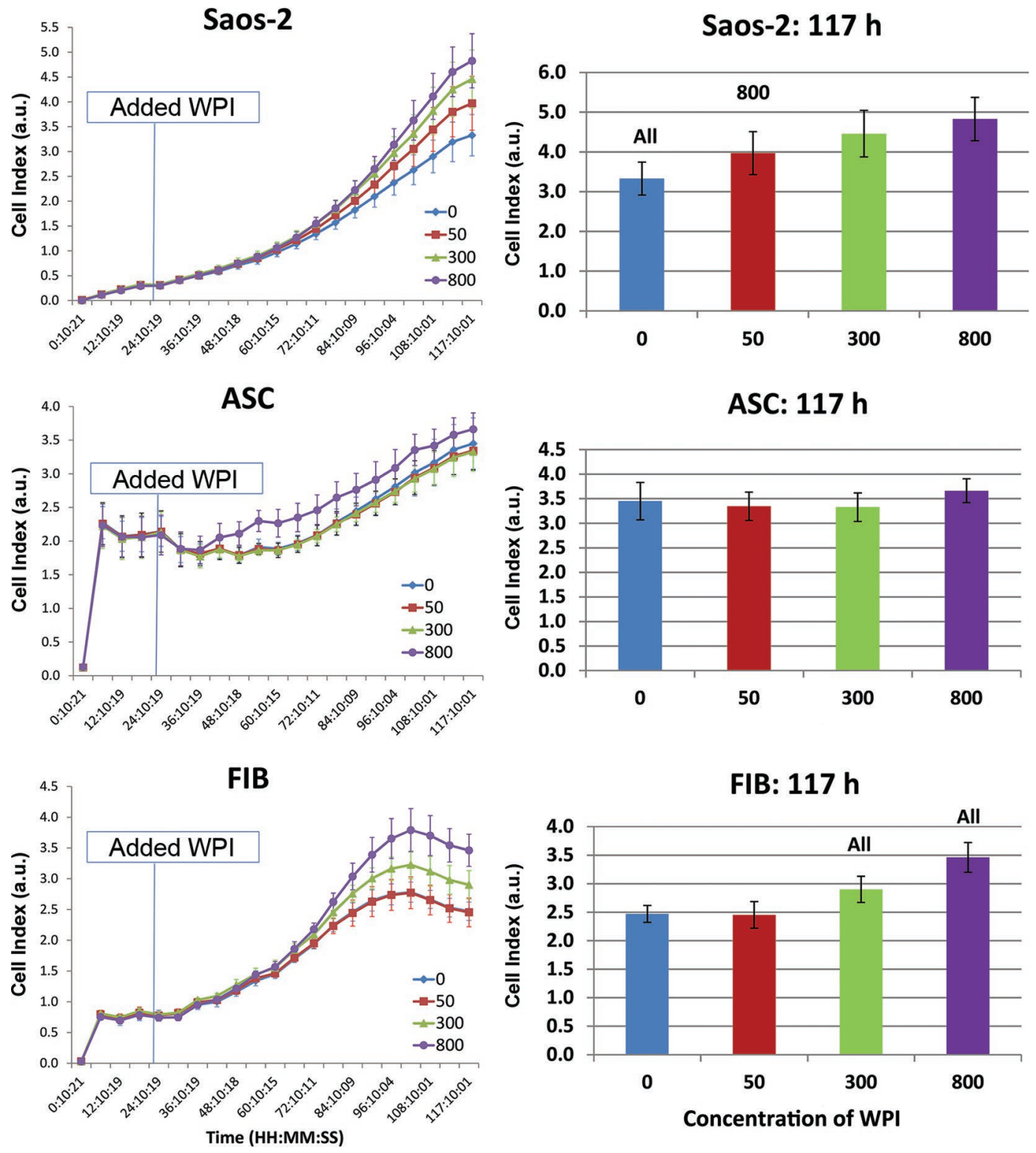

Figure 1. The growth curves represent proliferation of 3 types of cells measured with the xCELLigence system (Roche Applied Science, Mannheim, Germany): osteoblast-like cells (Saos-2), adipose-derived stem cells (ASC), and human neonatal dermal fibroblasts (FIB). After 24 $\mathrm{h}$, proliferative medium was replaced by medium containing different concentrations of whey protein isolate (WPI; $0,50,300$, or $800 \mu \mathrm{g} / \mathrm{mL}$ ). Graphs represent cell number (estimated as a cell index in arbitrary units, a.u.) at the last point of the measurement. For the statistical evaluation, the ANOVA Student-Newman-Keuls method was used. Statistical significance $(P \leq 0.05)$ : All = compared with all other tested groups, $800=$ compared with the cells grown in medium with $800 \mu \mathrm{g} / \mathrm{mL}$ WPI. Color version available online. 
suppression of osteoblast maturation and inhibits expression of late osteogenic markers (Liu et al., 2001). It has been reported that expression of $R U N X 2$ protected Saos-2 from the antiproliferative and apoptotic effects of tumor necrosis factor- $\alpha$ (Olfa et al., 2010). Whether the cells are of osteosarcoma or osteoblast origin is also important. The $R U N X 2$ gene is expressed at a lower level in several osteosarcoma cell lines; however, in Saos-2 cells (which also are of osteosarcoma origin), expression of $R U N X 2$ is increased (Cameron et al., 2003). The RUNX genes can act either as oncogenes or as tumor suppressors (Blyth et al., 2005). These reports are in accordance with our findings, where higher RUNX2 expression supported proliferation rather than differentiation of Saos-2 cells, but tended to have the opposite effect in ASC. Expression of COL1 was evaluated in all types of cells. Saos-2 cells did not respond to WPI, whereas expression of COL1 was significantly increased in ASC cultured in medium with $800 \mu \mathrm{g} / \mathrm{mL}$ WPI compared with other tested concentrations, and in FIB cultured in medium with 50,300 , or $800 \mu \mathrm{g} / \mathrm{mL}$ of WPI compared with WPI-free medium. The expression of $A L P$, which is considered an early or medium-term marker of cell differentiation, was improved in ASC with increasing concentrations of WPI. No effect was shown in Saos-2 cells. Expression of osteocalcin (OC), a late marker of osteogenic differentiation, was not influenced by increasing concentrations of WPI, in either Saos-2 cells or ASC. One explanation might be the relatively short culture interval of $7 \mathrm{~d}$ in our study, which might not be sufficient for expression of late markers of osteogenic cell differentiation. On the other hand, $O C$ expression can be enhanced in a shorter time interval if the culture conditions strongly promote osteogenic cell
Saos-2: RUNX2

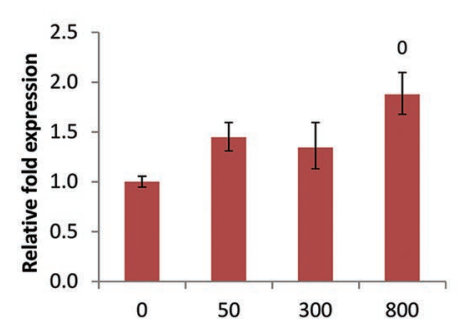

ASC: RUNX2

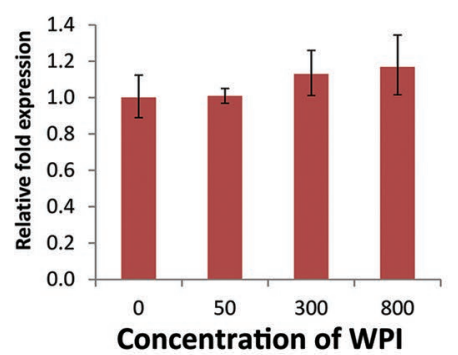

Saos-2: COL 1

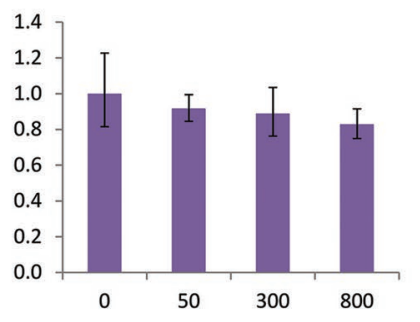

ASC: $C O L 1$

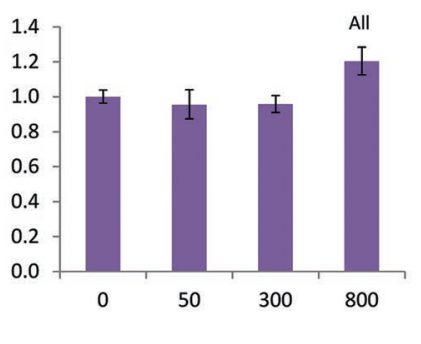

FIB: COL 1

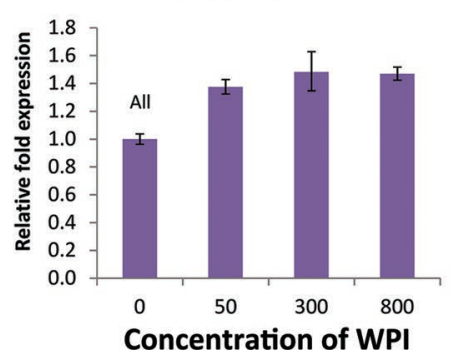

Saos-2: ALP

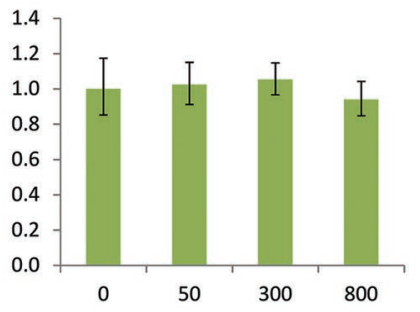

ASC: $A L P$

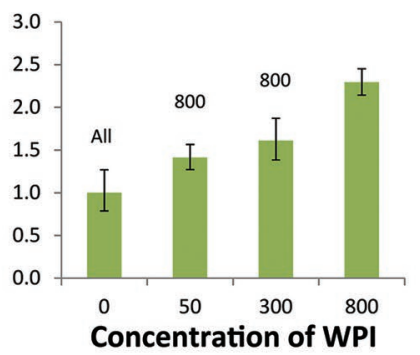

Saos-2: OC

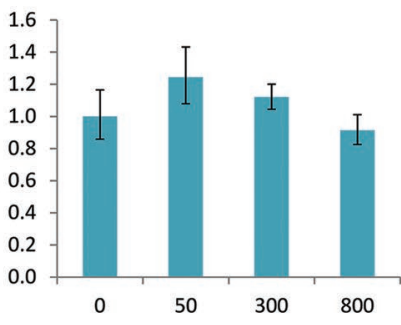

ASC: $O C$

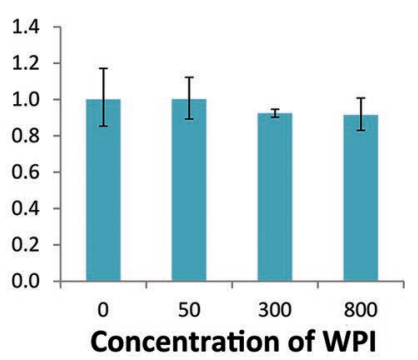

Figure 2. Real-time quantitative PCR results, with results expressed as relative fold expression compared with control values. Expression of transcription factor $R U N X 2$, type I collagen (COL1), alkaline phosphatase $(A L P)$, and osteocalcin $(O C)$ were evaluated on d 7 after seeding in the presence of different concentrations of whey protein isolate (WPI; 0, 50, 300, or $800 \mu \mathrm{g} / \mathrm{mL}$ ) in 3 cell types: osteoblast-like cells (Saos-2), adipose-derived stem cells (ASC), and human neonatal dermal fibroblasts (FIB). Data are presented as mean \pm SD, $\mathrm{n}=4$. Statistical analysis was performed for the cycle threshold values $(\Delta \mathrm{Cq})$. For the statistical evaluation, the ANOVA Student-Newman-Keuls method was used. Statistical significance $(P \leq 0.01)$ : All $=$ compared with all other tested groups; $800=$ compared with the cells grown in medium with $800 \mu \mathrm{g} /$ $\mathrm{mL}$ WPI. Color version available online. 
differentiation. For example, in our earlier study focusing on the effects of lactoferrin on the behavior of Saos2 cells, cells on collagen-lactoferrin coatings produced significantly higher levels of osteocalcin than cells on control polystyrene cell culture dishes (Vandrovcova et al., 2015). In the present study, where the effect of WPI on osteogenic cell differentiation appeared to be

\section{Saos-2: ALP Activity}
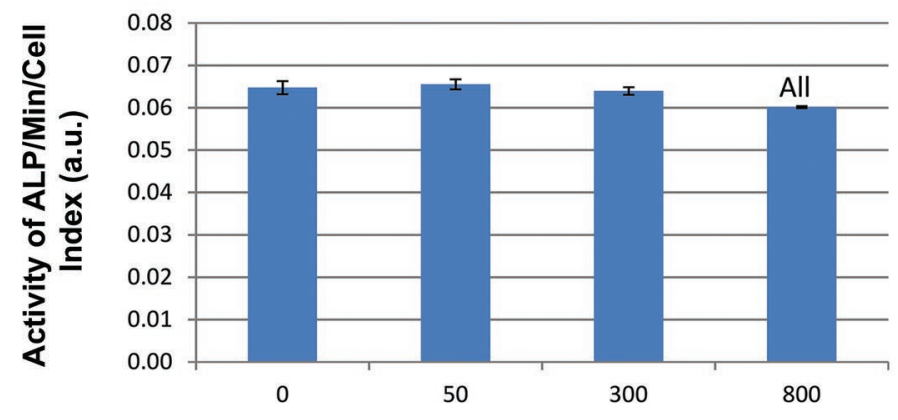

ASC: ALP Activity

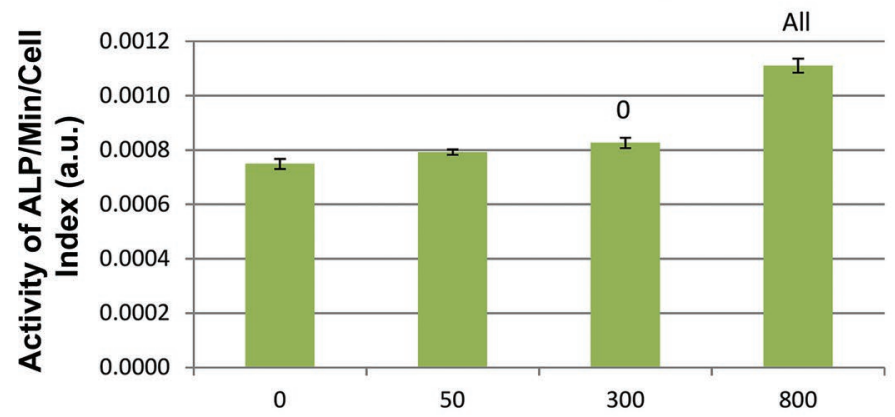

FIB: ALP Activity

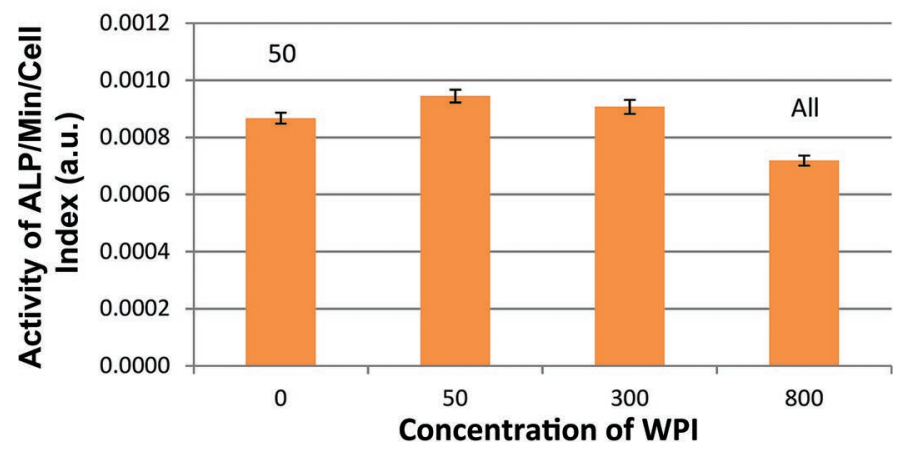

Figure 3. Activity of alkaline phosphatase (ALP) per minute and cell number (arbitrary units, a.u.) in 3 different cells types: osteoblastlike cells (Saos-2), adipose-derived stem cells (ASC), and human neonatal dermal fibroblasts (FIB) after seeding in the presence of different concentrations of whey protein isolate (WPI; 0, 50, 300, or $800 \mu \mathrm{g} /$ $\mathrm{mL}$ ). Data are presented as mean $\pm \mathrm{SD}, \mathrm{n}=4$. For the statistical evaluation, the ANOVA Student-Newman-Keuls method was used. Statistical significance $(P \leq 0.05)$ : All $=$ compared with all other tested groups; $0,50=$ compared with the cells grown in medium without WPI and with $50 \mu \mathrm{g} / \mathrm{mL}$ WPI. Color version available online. weaker, only early markers were detected after $7 \mathrm{~d}$ of cultivation. Thus, the osteogenic differentiation of cells under influence of WPI was in its early stage after $7 \mathrm{~d}$ but we expect that $O C$ would be increased after longer culture intervals.

The activity of ALP was evaluated on d 7 (Figure 3 ). Saos-2 cells are known to contain high amounts of ALP and the reaction had to be stopped after 5 min of incubation. Because of a relatively high content of ALP under standard cultivation conditions, no increase in ALP activity was found in Saos-2 cells in media with WPI; ASC showed slight activity of ALP close to the detection limit after $15 \mathrm{~min}$. The highest concentration of WPI $(800 \mu \mathrm{g} / \mathrm{mL})$ stimulated cells to produce a detectable ALP signal, which was in accordance with our PCR results. Similarly, the study by Xu (2009), performed on rat osteoblasts, showed that whey protein added in the culture medium stimulated the production of ALP in a dose-dependent manner. Fibroblasts are known not to contain ALP, so we decided to measure ALP activity in FIB as a negative control. The cells were exposed to the ALP substrate for $21 \mathrm{~min}$ and the values did not reach the limit of detection.

In view of the fact that ASC and FIB showed almost no activity of ALP (i.e., an enzyme involved in bone matrix mineralization), calcium deposition was evaluated only in Saos-2 cells after 14 and 21 d (Figure 4). After $7 \mathrm{~d}$ of cultivation, calcium deposition was low (below the limit of detection). Moreover, expression of early and medium-term markers of osteogenic cell differentiation (COL1 and $A L P)$ did not differ significantly in Saos-2 after $7 \mathrm{~d}$ of cultivation in media with various WPI concentrations. However, on d 14

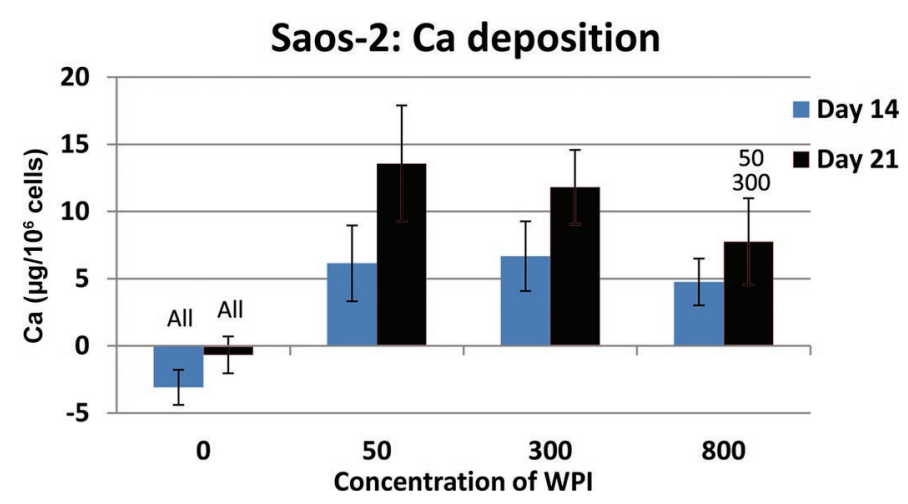

Figure 4. Calcium deposition by osteoblast-like cells (Saos-2) recalculated per cell number after seeding in the presence of different concentrations of whey protein isolate (WPI; 0, 50, 300, or $800 \mu \mathrm{g} /$ $\mathrm{mL})$. Data are presented as mean $\pm \mathrm{SD}, \mathrm{n}=4$. For the statistical evaluation, the ANOVA Student-Newman-Keuls method was used. Statistical significance $(P \leq 0.05)$ : All $=$ compared with all other tested groups; $50,300=$ compared with the cells grown in medium with 50 and $300 \mu \mathrm{g} / \mathrm{mL}$ WPI. Color version available online. 
after seeding, the influence of WPI was evident. On d 21 after seeding, the results were even more apparent. Nevertheless, in that time interval, the supportive effect was negatively correlated with increasing WPI concentration (Figure 4).

Besides the direct positive effects of WPI on proliferation of Saos-2 and FIB, and the osteogenic differentiation of ASC indicated by the results of this study, WPI has several other properties that may be advantageous in bone regeneration. Its main component, $\beta$-LG, has an affinity for hydrophobic molecules, which are poorly soluble in water, and $\beta-\mathrm{LG}$ can be used as a carrier protein to improve the solubility and bioavailability of hydrophobic molecules. Thus, $\beta-\mathrm{LG}$ could be used as a carrier or delivery protein for certain molecules that promote osteogenic differentiation, such as purmorphamine (Rezia Rad et al., 2016) or that are thought to promote bone healing, such as vitamin D (Gorter et al., 2014). In addition, WPI can be used to fabricate hydrogels (Puyol et al., 2001), which are gaining interest as biomaterials for bone regeneration (Gkioni et al., 2010). Furthermore, $\beta$-LG is inexpensive, as WPI is a commonly used food supplement (e.g., in bodybuilding; Marshall, 2004), and is thus produced in large quantities. Hence, we believe that applications of WPI in bone regeneration, both in solution and as a biomaterial component, are worthy of further investigation.

\section{CONCLUSIONS}

The growth of Saos- 2 cells and FIB was supported in an apparently dose-dependent manner by WPI. Expression of markers of osteogenic differentiation by ASC, such as COL1 and ALP, were improved by WPI in a concentration-dependent manner (the greatest degree of expression was found for $800 \mu \mathrm{g} / \mathrm{mL}$ of WPI). The expression of COL1 was also increased in FIB in the presence of WPI (compared with no WPI). The presence of WPI stimulated Saos-2 cells to deposit calcium even in standard culture medium without osteogenic supplements. We conclude that WPI has a positive effect on the growth of Saos- 2 cells and deposition of calcium by Saos-2, on the growth of FIB and their expression of type-I collagen, and on the osteogenic differentiation of ASC, as manifested by the expression of COL1 and ALP and the activity of ALP.

\section{ACKNOWLEDGMENTS}

This research work was financially supported by Agency for the Czech Republic Health Research, Ministry of Health of the Czech Republic (Prague; grant no. 15-33018A). Timothy Douglas acknowledges Fonds
Wetenschappelijk Onderzoek (Brussels, Belgium) for a postdoctoral fellowship. Andre Skirtach acknowledges Basis Onderzoeksfonds of Ghent University and ERANet Rus project "Intelbiocomp" (Belgium) for financial support.

\section{REFERENCES}

Bhattacharya, I., C. Ghayor, and F. E. Weber. 2016. The use of adipose tissue-derived progenitors in bone tissue engineering- $\mathrm{A}$ review. Transfus. Med. Hemother. 43:336-343.

Blyth, K., E. R. Cameron, and J. C. Neil. 2005. The RUNX genes: Gain or loss of function in cancer. Nat. Rev. Cancer 5:376-387.

Bounous, G., and P. Gold. 1991. The biological activity of undenatured dietary whey proteins: Role of glutathione. Clin. Invest. Med. 14:296-309.

Cameron, E. R., K. Blyth, L. Hanlon, A. Kilbey, N. Mackay, M. Stewart, A. Terry, F. Vaillant, S. Wotton, and J. C. Neil. 2003. The runx genes as dominant oncogenes. Blood Cells Mol. Dis. 30:194200.

Czekanska, E. M., M. J. Stoddart, R. G. Richards, and J. S. Hayes. 2012. In search of an osteoblast cell model for in vitro research. Eur. Cell. Mater. 24:1-17.

Diarrassouba, F., G. Garrait, G. Remondetto, P. Alvarez, E. Beyssac, and M. Subirade. 2015. Food protein-based microspheres for increased uptake of vitamin D3. Food Chem. 173:1066-1072.

Do, A. B., K. Williams, and O. T. Toomer. 2016. In vitro digestibility and immunoreactivity of bovine milk proteins. Food Chem. 190:581-587.

Estes, B. T., B. O. Diekman, J. M. Gimble, and F. Guilak. 2010. Isolation of adipose-derived stem cells and their induction to a chondrogenic phenotype. Nat. Protoc. 5:1294-1311.

Fakhry, M., E. Hamade, B. Badran, R. Buchet, and D. Magne. 2013. Molecular mechanisms of mesenchymal stem cell differentiation towards osteoblasts. World J. Stem Cells 5:136-148.

Flower, D. R., A. C. T. North, and C. E. Sansom. 2000. The lipocalin protein family: Structural and sequence overview. Biochim. Biophys. Acta 1482:9-24.

Frank, O., M. Heim, M. Jakob, A. Barbero, D. Schafer, I. Bendik, D. Walter, M. Heberer, and I. Martin. 2002. Real-time quantitative RT-PCR analysis of human bone marrow stromal cells during osteogenic differentiation in vitro. J. Cell. Biochem. 85:737-746.

Franke, S., H. Siggelkow, G. Wolf, and G. Hein. 2007. Advanced glycation endproducts influence the mRNA expression of RAGE, RANKL and various osteoblastic genes in human osteoblasts. Arch. Physiol. Biochem. 113:154-161.

Gillespie, A. L., D. Calderwood, L. Hobson, and B. D. Green. 2015. Whey proteins have beneficial effects on intestinal enteroendorine cells stimulating cells growth and increasing the production and secretion of incretin hormones. Food Chem. 189:120-128.

Gkioni, K., S. C. G. Leeuwenburgh, T. E. L. Douglas, A. G. Mikos, and J. A. Jansen. 2010. Mineralization of hydrogels for bone regeneration. Tissue Eng. Part B Rev. 16:577-585.

Gorter, E. A., N. A. T. Hamdy, N. M. Appelman-Dijkstra, and I. B. Schipper. 2014. The role of vitamin D in human fracture healing: A systematic review of the literature. Bone 64:288-297.

Ha, H. K., J. W. Kim, M. R. Lee, and W. J. Lee. 2013. Formation and characterization of quercetin-loaded chitosan oligosaccharide/ $\beta$ lactoglobulin nanoparticle. Food Res. Int. 52:82-90.

Jurgens, W. J., M. J. Oedayrajsingh-Varma, M. N. Helder, B. Zandiehdoulabi, T. E. Schouten, D. J. Kuik, M. J. Ritt, and F. J. van Milligen. 2008. Effect of tissue-harvesting site on yield of stem cells derived from adipose tissue: Implications for cell-based therapies. Cell Tissue Res. 332:415-426.

Keppler, J. K., D. Martin, V. M. Garamus, C. Breton-Carabin, E. Nipoti, T. Coenye, and K. Schwarz. 2017. Functionality of whey proteins covalently modified by allyl isothiocyanate. Part 1: Physicochemical and antibacterial properties of native and modified whey proteins at pH 2 to 7. Food Hydrocoll. 65:130-143. 
Keppler, J. K., and K. Schwarz. 2017. Increasing the emulsifying capacity of whey proteins at acidic $\mathrm{pH}$ values through covalent modification with allyl isotiocyanate. Colloids Surf. A Physicochem. Eng. Asp. 522:514-524.

Keppler, J. K., F. D. Sönnichsen, P. C. Lorenzen, and K. Schwarz. 2014. Differences in heat stability and ligand binding among $\beta$-lactoglobulin genetic variants $\mathrm{A}, \mathrm{B}$ and $\mathrm{C}$ using $1 \mathrm{H} \mathrm{NMR}$ and fluorescence quenching. Biochim. Biophys. Acta 1844:1083-1093.

Kolaparthy, L. K., S. Sanivarapu, S. Moogla, and R. S. Kutcham. 2015. Adipose tissue-Adequate, accessible regenerative material. Int. J. Stem Cells 8:121-127.

Kontopidis, G., C. Holt, and L. Sawyer. 2004. Invited review: $\beta$-lactoglobulin: Binding properties, structure, and function. J. Dairy Sci. 87:785-796.

Lee, M. R., H. N. Choi, H. K. Ha, and W. J. Lee. 2013. Production and characterization of beta-lactoglobulin/alginate nanoemulsion containing coenzyme Q10: Impact of heat treatment and alginate concentrate. Korean J. Food Sci. Anim. Resour. 33:67-74.

Levi, B., and M. T. Longaker. 2011. Adipose derived stromal cells for skeletal regenerative medicine. Stem Cells 29:576-582.

Liu, W., S. Toyosawa, T. Furuichi, N. Kanatani, C. Yoshida, Y. Liu, M. Himeno, S. Narai, A. Yamaguchi, and T. Komori. 2001. Overexpression of Cbfa1 in osteoblasts inhibits osteoblast maturation and causes osteopenia with multiple fractures. J. Cell Biol. 155:157-166.

Mahmud, R., M. A. Matin, and H. Otani. 2004. Mitogenic effect of bovine $\beta$-lactoglobulin and its proteolytic digests on mouse spleen resting cells. Pak. J. Biol. Sci. 7:2045-2050.

Marshall, K. 2004. Therapeutic applications of whey protein. Altern. Med. Rev. 9:136-156.

Mizuno, H. 2009. Adipose-derived stem cells for tissue repair and regeneration: Ten years of research and a literature review. J. Nippon Med. Sch. 76:56-66.

Moulti-Mati, F., A. Mati, J. Capiaumont, F. Belleville, G. Linden, and P. Nabet. 1991. Rôle de la $\beta$-lactoglobuline dans l'activité proliférative du lactosérum. Lait 71:543-553.

Olfa, G., C. Christophe, L. Philippe, S. Romain, H. Khaled, H. Pierre, B. Odile, and D. Jean-Christophe. 2010. RUNX2 regulates the effects of TNFa on proliferation and apoptosis in SaOs-2 cells. Bone 46:901910.

Parodi, P. W. 2007. A role for milk proteins and their peptides in cancer prevention. Curr. Pharm. Des. 13:813-828.

Pereira, P. C. 2014. Milk nutritional composition and its role in human health. Nutrition 30:619-627.
Puyol, P., M. D. Pérez, and D. S. Horne. 2001. Heat-induced gelation of whey protein isolates (WPI): effect of $\mathrm{NaCl}$ and protein concentration. Food Hydrocoll. 15:233-237.

Pyo, M. C., S. Y. Yang, S. H. Chun, N. S. Oh, and K. W. Lee. 2016. Protective effects of Maillard reaction products of whey protein concentrate against oxidative stress through an Nrf2-dependent pathway in HepG2 cells. Biol. Pharm. Bull. 39:1437-1447.

Reseland, J. E., S. Reppe, A. M. Larsen, H. S. Berner, F. P. Reinholt, K. M. Gautvik, I. Slaby, and S. P. Lyngstadaas. 2006. The effect of enamel matrix derivative on gene expression in osteoblasts. Eur. J. Oral Sci. 114:205-211.

Rezia Rad, M., M. Khojaste, M. Hasan Shahriari, S. Asgary, and A. Khojasteh. 2016. Purmorphamine increased adhesion, proliferation and expression of osteoblast phenotype markers of human dental pulp stem cells cultured on beta-tricalcium phosphate. Biomed. Pharmacother. 82:432-438.

Schliemann, B., D. Wähnert, C. Theisen, M. Herbort, C. Kösters, M. J. Raschke, and A. Weimann. 2015. How to enhance the stability of locking plate fixation of proximal humerus fractures? An overview of current biomechanical and clinical data. Injury 46:1207-1214.

Shields, L. B., G. H. Raque, S. D. Glassman, M. Campbell, T. Vitaz, J. Harpring, and C. B. Shields. 2006. Adverse effects associated with high-dose recombinant human bone morphogenetic protein-2 use in anterior cervical spine fusion. Spine 31:542-547.

Tschumperlin, D. J. 2013. Fibroblasts and the ground they walk on Physiology (Bethesda) 28:380-390.

Vandrovcova, M., T. E. L. Douglas, S. Heinemann, D. Scharnweber, P. Dubruel, and L. Bacakova. 2015. Collagen-lactoferrin fibrillar coatings enhance osteoblast proliferation and differentiation. J. Biomed. Mater. Res. A 103:525-533.

Walzem, R. L., C. J. Dillard, and J. B. German. 2002. Whey components: Millennia of evolution create functionalities for mammalian nutrition: What we know and what we may be overlooking. Crit. Rev. Food Sci. Nutr. 42:353-375.

$\mathrm{Xu}, \mathrm{R}$. 2009. Effect of whey protein on the proliferation and differentiation of osteoblasts. J. Dairy Sci. 92:3014-3018.

Yamaguchi, M., S. Takai, A. Hosono, and T. Seki. 2014. Bovine milkderived $\alpha$-lactoglobulin inhibits colon inflammation and carcinogenesis in azosymethane and dextran sodium sulfate-treated mice. Biosci. Biotechnol. Biochem. 78:672-679.

Zhang, L., X. Ren, E. Alt, X. Bai, S. Huang, Z. Xu, P. M. Lynch, M. P. Moyer, X.-F. Wen, and X. Wu. 2010. Chemoprevention of colorectal cancer by targeting APC-deficient cells for apoptosis. Nature 464:1058-1061. 